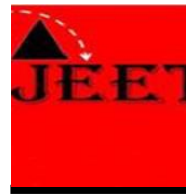

Journal of English Education and Teaching (JEET)

e-ISSN: 2622-5867

p-ISSN: 2685-743x

Volume 5 number 3, 2021

Page 317-329

\title{
Putting Edmodo Into Classroom: Portraying Learning Management System (LMS)
} Manifestation

\author{
Nasrullah \\ Universitas Lambung Mangkurat \\ Email: nasrullah01@ulm.ac.id \\ Asmi Rusmanayanti \\ Eötvös Loránd University \\ Email: asmi_rusmanayanti@ulm.ac.id \\ Elsa Rosalina \\ Universitas Lambung Mangkurat \\ Email: elsa.rosalina@ulm.ac.id \\ Rahma Pitria Ningsih \\ Politeknik Negeri Banjarmasin \\ Email: rahmapitria@poliban.ac.id \\ Corresponding email: nasrullah01@ulm.ac.id
}

\begin{abstract}
An array of teaching tools has been developed enormously today sparking interest for educators in their instruction. Edmodo, which is also one of the CALL applications that can be accessed online both from computer and mobile telephone is one option for teachers and students and can be operated to post various things related to EFL teaching-learning process. However, many educators are reluctant to embed with them pedagogical function which coming along in the use of Edmodo. This research employed a quantitative study with survey and interview for confirming data. This research involved twenty-five English Language Education students who are taking Extensive Reading course. This research contributes to picture out perception in implementing Edmodo as Web-Quest as well Learning Management System (LMS) in online classroom instructional activities. The result of this study highlights advantages and disadvantages presented though perceptions in the using of Edmodo as Learning Management System. The finding reveals that the involvement of Edmodo to material delivery still does not encounter the predicted expectation. The limited storing material in the application and lack of feedback of the task through the media are the reasons of the barrier. Despite the flaws that have been found, Edmodo is still perceived highly in catering the students' learning experience, developing understanding and evaluating skills, fostering teamwork and discussion skills, and feeling an easiness of task access. It is recommended that the use of Edmodo needs to be developed along with the various needs of students centered activities.
\end{abstract}

Keywords: Edmodo; learning management system (LMS); online application. 


\section{Introduction}

The drive of having technology into classroom rooted to online practice has been developed lately today. The involvement of online application and web tools to present material is also one of the moves that can be seen regularly adopting the spirit of the newest style. Even International Society for Technology in Education (2017), suggests that all teachers better use online community of practice for learning and professional growth prospects.

The study conducted by several scholars emphasizes that teachers are motivated to participate in online spaces because they provide instant access to people, resources, and knowledge that will help them improve their practice (Carpenter \& Krutka, 2014; Kelly \& Antonio, 2016; Seo, 2015; Trust, 2016). As online learning comes into higher education, it needs managements to be well adapted used as Learning Management System (LMS). LMS are systems that can make the activity of storing, managing, and modifying educational content. In other words, LMS is sets of network and technological tools that enable and facilitate online learning. They allow communication, sharing of information, submission of assignments, and related activities between learners and instructors (Gabrina \& Rahmawati, 2019). In this case, Edmodo and other type of web-quests, such as Moodle and Schology, are run based on such a type of that system.

Kumar (2012) explained that Edmodo is an online social learning platform designed by Jeff O' Hara and Nick Borg in 2008 which is used for students, teachers, schools, parents and even districts. Edmodo is an educational network that aims to facilitate teachers to link and interact with students and parents. In addition, Ekici (2017) claimed that most of the primary pre-service teachers stated that the use of the Edmodo application in teacher education had a positive effect on their pedagogical knowledge.

Edmodo as social networking tool which supports a spot for teachers and students to maximize interaction with them is usually used as learning Management System. However, one of the hidden gems in Edmodo is the "subject communities" feature that allows teachers to find and share subject-specific, practice- based knowledge with thousands of members. In the past 5 years, membership in many of these communities has grown to more than 500,000 members. In addition, according to Gabrina \& Rahmawati (2019), Edmodo as a tool promotes student collaborations 
and knowledge construction. Edmodo gives benefits to a practice of teaching and learning process.

The Edmodo subject communities are ripe for exploration with a massive membership base and opportunities for member-driven, bottom-up learning. By understanding how participation in these online space's shapes teaching and learning, researchers and educators can determine when and how to use these spaces for learning, and also can provide better support for teachers as they engage in these online spaces. Additionally, by taking a closer look at the Edmodo subject communities, administrators can determine whether these online spaces might complement current teacher professional development opportunities within their schools or districts. However, it is interesting to highlight what has been said technology skills alone cannot guarantee the effective use of technology in the classroom (Hursen, 2018). Therefore, to see the possibility of this phenomenon whether the use of Edmodo has the same treat to the other technological tools, or are there other interventions affect the attitude of users creates the prompt to this study.

In this regard, a few researches have been discussed on the elaboration of the use of EDMODO as well as what makes this study different. Firstly, the research results conducted by Al-Said (2015) showed that most students have positive perceptions towards Edmodo as an application for Mobile learning environment because it has many benefits in supporting the learning process such as facilitating and increasing effectiveness in the communication of learning, and they appreciated Edmodo since its allows them to learn at the right time, but every new learning environment has some barriers, and Edmodo and M-learning environment is not different. Then, Messaoudi (2021) found that the Edmodo learning management system has the potential to push content delivery, receipt, mastery, and assessment in ESP courses to the next level. Both of these two researches have attempted to find out the best Learning management system can be used for distance teaching based on the students' perspectives. However, both of the studies still do not seek for the positioning of Edmodo in the lens of students to shape the value and experience while learning via this learning management system. In this respect, to fill the void, this study aims at highlighting some important points in the use of Edmodo for teaching learning process rather than to discover whether this Learning Management System is better than the others or as a contrary, such as finding out whether Edmodo contributes positively in learning experience or if Edmodo sharpen the students' value, understanding and 
evaluating ability, logical and Critical thinking, discussion skills or other learning expected learning qualities.

\section{Research Methodology}

This study employed quantitative study by involving students who take Extensive Reading Course. In this study, they were recruited to be involved and share their experiences of learning while using Edmodo as learning management system (LMS). Twenty-five students of the fifth semester students were involved because this course they are taking in this term. Cluster random sampling technique used in this study. While why the Extensive Reading Course was taken because this course had variety of learning activities such sharing stories and its feedback addressed by both lecturers and students, reflection written Journal and other activities to construct knowledge together in group assignment.

The questionnaire was used here along with interview to get the data. Adapted from Brady et al., (2010)'s questionnaire then validated by expert to make sure that the questionnaire can be used for this study. This instrument used 20 questions to get the data in which close-ended questions are applied. The participants answered this questionnaire using strongly disagree, disagree, neutral, agree, and strongly agree. The indicators of the questionnaire based on participant's response through this questionnaire. If most participants answered agree and strongly agree meant that the question got high interpretation level. In addition, the other data were collected using interview.

Descriptive statistic was used for data analysis procedures in this study. It was because the presentation of data in the form of tables, graphic or lists to facilitate the observation and evaluation. Results of research are compiled in the form of tables and provide explanations using sentences on the presented data that has been obtained. The commonly used table types are frequency tables and graphic (Morissan, 2014).

\section{Findings and Discussion,}

\section{Findings}

The Table 1 showed that mostly students' perception toward Edmodo is medium while more than half respondents chose neither agree nor disagree. Moreover, seven out of twenty statements gained positive perceptions meaning that the other statements gained medium level or the students were still confused whether 
chose agree or disagree. This is occurred because the activity of lecturer and students use Edmodo just for sending and receiving assignment and there is less activity to make students interacts one another as it is reported by students' answers toward the use of Edmodo in and outside the classroom.

Table 1: The result of the questionnaire that has been answered by the respondents, including frequency, percentage, mean score and the interpretation level

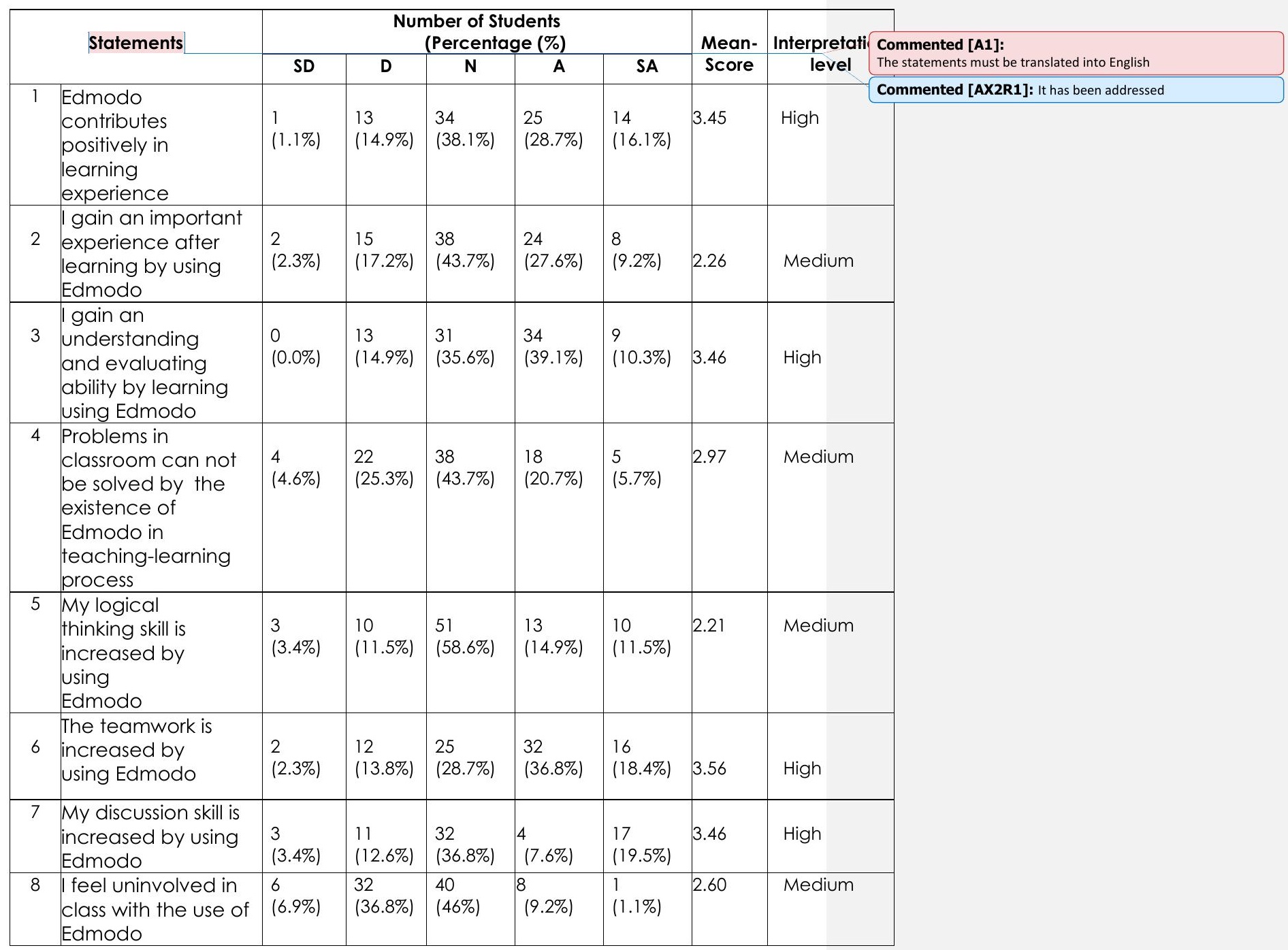


Putting Edmodo Into Classroom:

Portraying Learning Management System (LMS) Manifestation

\begin{tabular}{|c|c|c|c|c|c|c|c|c|}
\hline 9 & $\begin{array}{l}\text { I can find the } \\
\text { connection } \\
\text { between topic and } \\
\text { experience by using } \\
\text { Edmodo }\end{array}$ & $\begin{array}{l}2 \\
(2.3 \%)\end{array}$ & $\begin{array}{l}12 \\
(13.8 \%)\end{array}$ & $\begin{array}{l}44 \\
(50.6 \%)\end{array}$ & $\begin{array}{l}25 \\
(28.7 \%)\end{array}$ & $\begin{array}{l}4 \\
(4.6 \%)\end{array}$ & 2.21 & Medium \\
\hline 10 & $\begin{array}{l}\text { Critical thinking skill } \\
\text { can be increased by } \\
\text { using Edmodo }\end{array}$ & $\begin{array}{l}0 \\
(0.0 \%) \\
\end{array}$ & $\begin{array}{l}18 \\
(20.7 \%) \\
\end{array}$ & $\begin{array}{l}43 \\
(49.4 \%)\end{array}$ & $\begin{array}{l}20 \\
(23.0 \%)\end{array}$ & \begin{tabular}{|l}
6 \\
$(6.9 \%)$ \\
\end{tabular} & 2.17 & Medium \\
\hline 11 & $\begin{array}{l}\text { can share ideas } \\
\text { efficiently with the } \\
\text { use of Edmodo }\end{array}$ & $\begin{array}{l}8 \\
(9.2 \%)\end{array}$ & $\begin{array}{l}23 \\
(26.4 \%)\end{array}$ & $\begin{array}{l}27 \\
(31.0 \%)\end{array}$ & $\begin{array}{l}21 \\
(24.1 \%)\end{array}$ & $\begin{array}{l}8 \\
(9.2 \%)\end{array}$ & 2.96 & Medium \\
\hline 12 & $\begin{array}{l}\text { I always remember } \\
\text { the task with the } \\
\text { existence of } \\
\text { Edmodo }\end{array}$ & \begin{tabular}{|l}
2 \\
$(2.3 \%)$
\end{tabular} & 8 & $\begin{array}{l}21 \\
(24.1 \%)\end{array}$ & $\begin{array}{l}28 \\
(32.2 \%)\end{array}$ & $\begin{array}{l}28 \\
(32.2 \%)\end{array}$ & 3.28 & High \\
\hline 13 & $\begin{array}{l}\text { I like to ask questions } \\
\text { with the existence of } \\
\text { Edmodo }\end{array}$ & 5 & $\begin{array}{l}32 \\
(36.8 \%)\end{array}$ & $\begin{array}{l}33 \\
(37.9 \%)\end{array}$ & $\begin{array}{l}12 \\
(13.8 \%)\end{array}$ & 5 & 2.76 & Medium \\
\hline 14 & $\begin{array}{l}\text { gain the ease of } \\
\text { use with Edmodo }\end{array}$ & 3 & $\begin{array}{l}16 \\
(18.4 \%)\end{array}$ & $\begin{array}{l}44 \\
(50.6 \%)\end{array}$ & $\begin{array}{l}20 \\
(23.0 \%)\end{array}$ & $4(4.6 \%)$ & 2.05 & Medium \\
\hline 15 & $\begin{array}{l}\text { easily connect with } \\
\text { friends with Edmodo }\end{array}$ & $\begin{array}{l}10 \\
(11.5 \%)\end{array}$ & \begin{tabular}{|l|}
28 \\
$(32.2 \%)$
\end{tabular} & $\begin{array}{l}29 \\
(33.3 \%)\end{array}$ & $\begin{array}{l}15 \\
(17.2 \%)\end{array}$ & 5 & 2.73 & Medium \\
\hline 16 & $\begin{array}{l}\text { Edmodo provides } \\
\text { easy-task access }\end{array}$ & 0 & 6 & $\begin{array}{l}18 \\
(20.7 \%)\end{array}$ & $\begin{array}{l}38 \\
(43.7 \%)\end{array}$ & \begin{tabular}{|l|}
25 \\
$(28.7 \%)$
\end{tabular} & 3.92 & High \\
\hline 17 & $\begin{array}{l}\text { course materials are } \\
\text { easy to access with } \\
\text { Edmodo }\end{array}$ & 2 & $\begin{array}{l}14 \\
(16.1 \%)\end{array}$ & $\begin{array}{l}41 \\
(47.1)\end{array}$ & $\begin{array}{l}21 \\
(24.1 \%)\end{array}$ & 9 & 2.23 & Medium \\
\hline 18 & $\begin{array}{l}\text { The problem in } \\
\text { connection is } \\
\text { found when we } \\
\text { want to use } \\
\text { Edmodo }\end{array}$ & 2 & 9 & $\begin{array}{l}41 \\
(47.1 \%)\end{array}$ & $\begin{array}{l}14 \\
(16.1 \%)\end{array}$ & $\begin{array}{l}21 \\
(24.1 \%)\end{array}$ & 3.47 & High \\
\hline 19 & $\begin{array}{l}\text { found effective } \\
\text { communication with } \\
\text { Edmodo rather than } \\
\text { face-to-face } \\
\text { teaching learning }\end{array}$ & 8 & $\begin{array}{l}30 \\
(34.5 \%)\end{array}$ & $\begin{array}{l}37 \\
(42.5 \%)\end{array}$ & $\begin{array}{l}11 \\
(12.6 \%)\end{array}$ & 1 & 2.61 & Medium \\
\hline 20 & $\begin{array}{l}\text { Expressing ideas is } \\
\text { easier for me to do } \\
\text { with Edmodo }\end{array}$ & ${ }^{7}(8.0 \%)$ & \begin{tabular}{|l}
22 \\
$(25.3 \%)$
\end{tabular} & $\begin{array}{l}47 \\
(54.0 \%)\end{array}$ & $\begin{array}{l}11 \\
(12.6 \%)\end{array}$ & 0 & 2.70 & Medium \\
\hline
\end{tabular}


Since online learning has been popular in the pandemic time, many educators try to find out ways on how to hold the learning process effectively so that the aims of learning still can be achieved as planned. In this regard, some of them choose Edmodo as their learning management system. In relation to this finding on the table that many students place Edmodo as learning system which furnishes the learning experience. They rated in a high perception. This could be this way because Edmodo has developed its features which enable the learners to collaborate with other websites (embed features). Since students can go back and forth pertained teachers to instructional aims by using Edmodo, students can feel various experiences surfing with learning system.

Additionally, Edmodo can increase understanding because material for example which can be stored can be downloaded and played everywhere and anywhere. Besides, it also provides an easy access in evaluation since it provides variety of assessment formats. In that table above, students also put their perception in high category. It means Edmodo, up to this time, can one of the best LMS that can be used both for teachers/lecturers/ and for students.

Learning that can promotes the ability of logical and critical thinking are paid more attention nowadays. Eventhough the result table above elaborates that Edmodo can also become a trigger for logical and critical thinking in medium level, students are still invited to cater those two important skills through instructions that along with assignments given. Edmodo enables teachers to set the type of essay questions, to not mention the objective type of test variants, which lead the students to think logically.

The result above Interestingly presents that Edmodo can foster the collaboration and cooperation in high level. In learning language especially writing in English for example, students can give feedback over their peer works. Edmodo cater students as well as teachers with an interaction mode in the instilled feature for doing conversation in a chat box available. Similarly, the result table also pinpoints that the discussion skill of students is getting improved through this interaction. It even reports that this skill has progressed in high category. To this end, this LMS allows a collaboration, cooperation and excel the discussion skill in a well manner.

In summary, in the table above especially in the results of high perception in, it can be highlighted that by having Edmodo as students learning management system, students can retract focus to the lesson's aim and planning because there is a feature 
that can remind them via email or their mobile Edmodo application in their handphone. More importantly, the ability of having a good teamwork is strengthened by the existence of Edmodo because the group assignment given in this learning media makes enable them to work together with good communication in the chat (message) featured available.

In this respect, this study reveals that Edmodo contributes to their learning in understanding and evaluating viewpoints. Since Edmodo is a platform that can be accessed everywhere, the material is easily obtained by students wherever they are as long as they are connected with internet. Moreover, the understanding of students is shaped well as the material evaluation has been spotted in that platform. Furthermore, students perceived that by having discussing with other friends and teacher with the easily accessed material, learning community can be created to maximize the comprehensible input resulted in that way of learning. all in all, this reflection showed positive perceptions from students' learning experiences.

\section{Discussion}

The core of finding to this study highlights that the use of Edmodo for students is still neutral. In other words, if the lecturer uses it or not the impact toward learning is not significantly different. The matter here is whether the application has less function to be applied in the classroom or the users have less known in how to use it effectively and properly. Therefore, the use of Edmodo can bring about benefits and drawbacks.

The first benefit is basically Edmodo provides limited and moderated class Web pages to handle specific discussion and certain selected class. Thus, teacher or lecturer can provide many classes only in one application. The material provided can be retrieved easily online and every time and everywhere students need to access. Moreover, it is also supported by the result of study conducted in Malaysia and Saudi which reveals that Edmodo was perceived as an online resource or digital library by the student for the students who could access the material outside the classroom (Tavukcu, 2018; Gay \& Sofyan, 2017). The second advantage, there is a feature for parents to have an access to Edmodo to be a part of learning community as it concurs with Alamsyah et al., (2021) who commented that Edmodo enables learners to interact with each other closely, and contributes to positive learning community.

The other benefit, like the other learning application, Edmodo has basic function to run the class to have an access toward material, discuss with other users 
or students at the same time, variety of quiz format to assess learning progress or even join with learning community around the world. In addition, teachers can also share learning resources to the other colleagues. Trust (2016)emphasized that Edmodo facilitates learning reflection and promotes collaboration, specifically discussion with teachers and peers. As a result, the students feel that the Edmodo is interesting and attracting. This statement is matched to Greenhow \& Chapman (2020) who argues that social media like-features that Edmodo has, such as posting, comment and chat room, fascinate students to participate in the classroom activity.

According to Gay \& Sofyan (2017), Educators also have the ability to send alerts, events, and tasks for students and may decide to send something in a timeline that can be viewed by public. With this feature students feel more comfortable working on assignments using Edmodo because there are reminding when they have not done or have done doing assignments. Based on students' point of view, collecting assignments trough Edmodo is easier and feel saved because it will never loose, unless, their connection is not stable and the assignments that they uploaded is not send yet. In addition, students also feel helped to use Edmodo because of this feature, with lot of activities out of school they might forget about the task and Edmodo gives them alerts for this. This statement gained high interpretations which means Edmodo gives positive effects positive for students.

Regarding the drawbacks, there are several features that need to be understood well by the instructor. Even Edmodo has variety of quiz, it is just easily used for objective test, but hardly used for subjective test. It needs high intervention of instructor to check and evaluate tasks related to subjective test such as Essay. The other features which is absent from this application is the shortcut to make objective test such as the feature in uploading questions and options. Because of this, it is frequently that teachers or instructors find themselves taking long time only in putting the questions. The researcher believes that despite several weaknesses that Edmodo has, the developer of that application does upgrade the features and ability to meet the users' need in the future. These result is confirmed by Al-Said (2015) who claimed that every new learning environment has some barriers, and Edmodo and M-learning environment is the same reflection study on Edmodo as learning management system.

The finding of this study showed the blunt result in which the existence of new technological tools applied in the classroom does not change the perceptions of learners in receiving materials. It happens because of the fact that a less awareness 

given. In other words, as the tool of Learning Management System, the components which include schedule, announcement, syllabus, modules, assignment, discussion board, private message, chat, test, quizzes, and grade book as the set of material presentation should be prepared at the first hand; then, method of delivery as pedagogical approaches that have been selected rigorously should have been wellorganized as well. As it does not get proper attention, the adaptation in teaching material through technological tools will be hindered or result in the unexpected outcomes. What has happened is in harmony with the assertion of several researchers that increased access to technology does not mean increased use of technology in classrooms(Polat, 2016; Thang et al., 2016; Mei, 2019; Nasrullah, 2021).

It means even the surface and media of teaching delivery have changed drastically, the tendency of teaching approach or method is still not changing its look. In other words, many instructors use the recent technological tools with standard minimum of its function but not relevant yet with the variety of students learning style and learning need at current time in its plethora of technological variants. Hence, they get confused to select which ones that can work to help gaining learning outcomes best. On the contrary, the result is not in accordance with Al-Said's study (2015) which claims that students' views about Edmodo and Mobile Learning is in "High" level, and most of students have positive perceptions to Edmodo and Mobile Learning as they think that learning by using Edmodo enables and improves the communication effectiveness of learning.

Regarding to that case, as Learning Management System, even Edmodo is in underway to improve the quality of its application; at least there are many features that can be used integratedly to the other application such as Wikis, Blogs, Screen Cast o Matic, Camtasia, Padlet, or even Canva and any other web 2.0 based to raise students' progress to achieve predicted learning outcome. It can be taken place as long as the instructors are ready with pedagogical knowledge that suitable to its use. In spite of the benefits of Learning Management System, such as Edmodo, are limitless, but then unluckily there are some challenges and barriers appear in implementation of such learning form (Fitrawati, 2021). Furthermore, some of studies conducted by Hockly (2012); Johnson (2016); Kannan \& Munday (2018); and Royle et al., (2014) claimed that challenge and obstructions do exist, and these show the limitations or difficulties in the implementation of Mobile Learning in their countries. 


\section{Conclusion and Suggestion}

This study highlights the preference in using Edmodo for the university students that is still in medium level. In other words, the involvement of Edmodo to material delivery does not meet the predicted expectation due to the way of handling the course. It still drives to the basic need of running the course such as storing material in the application and giving the task without having sufficient feedback through media instead of some feedback even not all have been given in a face-to-face interaction in classroom. Based on this finding, it is pivotal that the use of Edmodo needs to be developed along with the mindset of students centered activity.

Even so, Edmodo promises a good prospective learning management system since it can furnish a distinctive learning experience, can promote a good understanding toward materials given, and can strengthen cooperation and collaboration skill for students. Furthermore, It is suggested that the tasks given in Edmodo should be based on activity which applied expected learning outcomes, from lower order thinking skill to higher order thinking skill. Therefore, the interplay of other applications with the using of Edmodo is expected. To meet the demand, the instructors should be familiar with e-skills and other digital literacy skills to incorporate materials with technological device so that the combination will provide sufficient resources and more meaningful experience for learners.

\section{References}

Al-Said, K. M. (2015). Students' perceptions of edmodo and mobile learning and their real barriers towards them. Turkish Online Journal of Educational Technology, $14(2), 167-180$.

Alamsyah, M., Marhento, G., Siburian, M. F., Astuti, I. A. D., \& Bhakti, Y. B. (2021). Application of blended learning with Edmodo based on POE learning model to increase students understanding of science concepts. Journal of Physics: Conference Series, 1806(1), 1-7. https://doi.org/10.1088/17426596/1806/1/012121.

Brady, K. P., Holcomb, L. B., \& Smith, B. V. (2010). The Use of alternative social networking sites in higher educational settings: A case study of the e-learning benefits of Ning in education. Journal of Interactive Online Learning, 9(2), 151170.

Carpenter, J. P., \& Krutka, D. G. (2014). How and why educators use Twitter: A survey of the field. Journal of Research on Technology in Education, 46(4), 414-434. https://doi.org/10.1080/15391523.2014.925701.

Ekici, D. I. (2017). The Use of Edmodo in Creating an Online Learning Community of Practice for Learning to Teach Science. Malaysian Online Journal of Educational Sciences, 5(2), 91-106. 
Fitrawati. (2021). Learning Management System and EFL Classes: A Way to Promote Autonomous Blended Learning. Journal of Physics: Conference Series, 1779(1), 18. https://doi.org/10.1088/1742-6596/1779/1/012030.

Gabrina, P. A. S., \& Rahmawati, F. (2019). Exploring the Use of Edmodo in an EFL Classroom. Journal of Foreign Languange Teaching and Learning, 4(2). https://doi.org/10.18196/ftl.4241.

Gay, E., \& Sofyan, N. (2017). the Effectiveness of Using Edmodo in Enhancing Studentsâ Outcomes in Advance Writing Course of the Fifth Semester At Fip - Ummu. Journal of English Education, 2(1), 1-11.

Greenhow, C., \& Chapman, A. (2020). Social distancing meet social media: digital tools for connecting students, teachers, and citizens in an emergency. Information and Learning Science, 121 (5-6), 331-342. https://doi.org/10.1 108/ILS04-2020-0134.

Hockly, N. (2012). Digital literacies. ELT Journal, 66(1), 108-112. https://doi.org/10.1093/elt/ccr077.

Hursen, C. (2018). The impact of Edmodo-assisted project-based learning applications on the inquiry skills and the academic achievement of prospective teachers. TEM Journal, 7(2), 446-455. https://doi.org/10.18421/TEM72-29.

International Society for Technology in Education. (2017). ISTE Standards for Educators. Journal of Research in Technology in Education, 1-2. https://www.iste.org/standards/iste-standards-for-teachers.

Johnson, L. (2016). Writing 2.0: How English Teachers Conceptualize Writing with Digital Technologies. English Education, 49(1), 28.

Kannan, J., \& Munday, P. (2018). New trends in second language learning and teaching through the lens of ICT, networked learning, and artificial intelligence. Circulo de Linguistica Aplicada a La Comunicacion, 76, 13-30. https://doi.org/10.5209/CLAC.62495.

Kelly, N., \& Antonio, A. (2016). Teacher peer support in social network sites. Teaching and Teacher Education, 56, 138-149. https://doi.org/10.1016/j.tate.2016.02.007

Kumar, U. (2012). Nicolas Borg and Jeff O'Hara: Founders of Edmodo, the Largest Social Network for School Students and Teachers. Brain Prick. http://brainprick.com/nicolas-borg-and-jeff-ohara-founders-of-edmodo-thelargest-social-network-for-school-students-and-teachers/

Mei, B. (2019). Preparing preservice EFL teachers for CALL normalisation: A technology

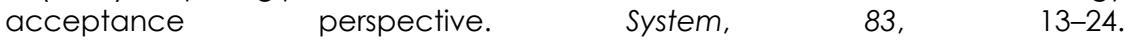
https://doi.org/10.1016/j.system.2019.02.011.

Messaoudi, M. El. (2021). The use of learning management systems in ESP to explore postgraduate students ' content knowledge about epidemiology and COVID19 : a mixed-methods study. Educational Process: International Journal, 10(2), 5982.

Morissan. (2014). Metode penelitian survey. Jakarta: Kencana Prenadamedia Group.

Seo, K., \& Han, Y. K. (2013). Online teacher collaboration: A case study of voluntary collaboration in a teacher-created online community. KEDI Journal of Educational Policy, 10(2), 221-242, 2013.

Nasrullah. (2021). Pre-service and in-service English teachers' outlook in the use of online learning. UAD TEFL International Conference, 2, 54. https://doi.org/10.12928/utic.v2.5736.2019.

Polat, M. (2016). Emerging technologies in language pedagogy: Language learners' perceptions through the lenses of innovation diffusion and user intention theories. Proquest Dissertations and Theses, 214. https://search.proquest.com/docview/1797593494?accountid=15928\%0Ahttp:// 
onesearch.unifi.it/openurl/39UFI/39UFI_Services?tabs=viewOnlineTab\&?url_ver=Z $39.88-$

2004\&rft_val_fmt=info:ofi/fmt:kev:mtx:dissertation\&genre=dissertations+\%26+thes es\&sid=ProQ:ProQuest+.

Royle, K., Stager, S., \& Traxler, J. (2014). Teacher development with mobiles: Comparative critical factors. Prospects, 44(1), 29-42. https://doi.org/10.1007/s $11125-013-9292-8$.

Seo, Y. (2015). Daily water level forecasting using wavelet decomposition and artificial intelligence techniques. Journal of Hydrology, 520, 224-243. https://doi.org/10.1016/j.jhydrol.2014.11.050.

Tavukcu, T. (2018). The impact of Edmodo assisted education on project evaluation achievement scores and determination of opinions for use in education. TEM Journal, 7(3), 651-657. https://doi.org/10.18421/TEM73-23.

Thang, S. M., Lee, K. W., Murugaiah, P., Jaafar, N. M., Tan, C. K., \& Bukhari, N. I. A. (2016). ICT tools patterns of use among malaysian university students ESL. GEMA Online Journal of Language Studies, 16(1), 49-65.

Trust, T. (2016). New Model of Teacher Learning in an Online Network. Journal of Research on Technology in Education, 48(4), 290-305. https://doi.org/10.1080/15391523.2016.1215169. 